\title{
Prevalence of Diseases caused by White Spot Virus and Enterocytozoon Hepatopenaei in Penaeus vannamei Shrimp Farms in Nagapattinam District, Tamil Nadu, India
}

A. Rathipriya ${ }^{1 *}$, T. Anand ${ }^{2}$, A. Uma ${ }^{3}$ and K. Karal Marx ${ }^{1}$

${ }^{1}$ Institute of Fisheries Post Graduate Studies, TNJFU-OMR campus, Vaniyanchavadi, Chennai, India

${ }^{2}$ College of Fisheries Engineering, Tamil Nadu Dr J. Jayalalithaa Fisheries University, Nagapattinam, India

${ }^{3}$ Dr. MGR. Fisheries College and Research Institute, Ponneri, Chennai, India

*Corresponding author

\section{Keywords}

P. vannamei, Shirmp farming, Hepatopancreatic microsporidiosis, Better management practices

Article Info

Accepted:

20 May 2019

Available Online:

10 June 2019

\begin{abstract}
Disease is one of the major factors affecting the development and sustainability of aquaculture. White spot disease caused by white spot syndrome virus (WSSV) results in severe production and economic losses to the shrimp farming industry worldwide. Recently, Hepatopancreatic microsporidiosis caused by Enterocytozoon hepatopenaei (EHP) a microsporidian parasite has been reported to cause severe growth retardation and losses in commercial Penaeus vannamei farming. In the present study, we report the prevalence of white spot syndrome virus and hepatopancreatic microsporidiosis in the $P$. vannamei shrimp farms in Nagapattinam district, Tamil Nadu, India. This study was undertaken in a total number of 57 selected P. vannamei farms in Nagapattinam district, Tamil Nadu during the period from October 2016 to September 2017. P. vannamei samples collected at fortnight intervals were screened for WSSV and EHP by PCR. The results showed that the prevalence of diseases caused by WSSV and EHP were $49.12 \%$ and $66.66 \%$ respectively. This report alerts the farmers for the adoption of better management practices to be followed so as to prevent these diseases and improve the production and sustainability in $P$. vannamei farming.
\end{abstract}

\section{Introduction}

Total shrimp production in the world is dominated by $P$. vannamei and $P$. monodon which contributes around $80 \%$ of total shrimp production (FAO, 2009). In the worldwide the dominance of $P$. vannamei over $P$. monodon is due to its availability of SPF, SPR brood stock, fast growth rate and low protein requirement. The global production of crustaceans was about 4128 million tonnes in quantity. China remains to be the top producer of crustaceans globally with $32.5 \%$ of production and India stands at sixth place with around $7.0 \%$ of production (FAO statistics, 2016). In the shrimp culture system, most of the disease incidence has been attributed to viral pathogens (Kiran and Salim, 2012). But in recent years, there has been incidence of new parasitic pathogens 
that has caused severe economic losses to the farmers. Such emerging diseases include WSSV and hepatopancreatic microsporidiosis (HPM), and so on. Since July 1994, the Indian shrimp industry has been under the clutch of disease mainly WSSV and it has washed out most of the farms in India. White spot disease (WSD) was first reported in 1992 in cultured kuruma shrimp ( $P$. japonicus) in the Fujian province of china and in nearby Taiwan (Zhan et al., 1998 and Jiang 2001) and later it had spread to most shrimp farming countries throughout south and south-east Asia. In India, WSSV was first reported in 1994 in black tiger shrimp ( $P$. monodon) from Visakhapatnam of Andhra Pradesh to sirkali of Tamil Nadu. It cause disease and mortality reaching upto $100 \%$ within 2-10 days after the onset of symptoms (Lightner 1996 and $\mathrm{Xu}$ et al., 2006).WSSV has emerged as a major threat to the commercial penaeid shrimp farming globally as it has caused mortalities and consequent serious damage to the shrimp culture industry since, 1992 (Inouye et al., 1994, Chou et al., 1995, Wongteerasupaya et al., 1995, Lo et al., 1996, and Karunasagar et al., 1997). WSSV infection results in a rapid onset of the disease and high mortality of upto $100 \%$ within 3-10 days in P. monodon (Cai et al., 1995) and P. vannamei. The major targets of for WSSV infection are tissues of ectodermal and mesodermal origin such as the gills, lymphoid organ, cuticle epithelium, nervous tissue and muscle (Chang et al., 1996). Enterocytozoon hepatopenaei (EHP) is a microsporidian parasite that was first characterized and named from the giant or black tiger shrimp $P$. monodon from Thailand in 2009 (Tourtip et al., 2009). It was discovered in slow growing shrimp but was not statistically associated with slow growth at that time. EHP is confined to the shrimp hepatopancreas (HP) and morphologically resembles an unnamed microsporidian, previously reported in the HP of $P$. japonica from Australia in 2001. Together, these studies suggest that EHP is not an exotic pathogen but that it is endemic to Australia. Later, it was found that EHP could also infect exotic P. vannamei imported for cultivation in Asia and that it could be transmitted directly from shrimp to shrimp by the oral route (Tangprasittipap et al., 2013). This differed from the most common microsporidian previously reported from cotton shrimp, where transmission required an intermediate fish host, allowing disruption of transmission by exclusion of fish from the production system. Rajendran et al., (2016) have reported the incidence of EHP in India. Against this background, the study was carried out with an objective to understand the prevalence of WSSV and an EHP disease which is severely affect the shrimp production in the nagapattinam district, which is one of the major shrimp farming districts of Tamil Nadu, India.

\section{Materials and Methods}

The experiment was conducted at 57 farms (in and around farms of the ten creeks) located in Nagapattinam district Tamil Nadu, India for the period from October 2016 to September 2017. The sampling sites were shown in figure 1 and Table 1.

\section{Sample collection}

Samples of juveniles and adults of $P$. vanammei culture ponds were collected from the shrimp farms. Samples of live shrimp were collected and fixed onsite using $70 \%$ ethyl alcohol for PCR.

\section{PCR diagnosis}

Genomic DNA was extracted from the gills and hepatopancreas of juveniles (Fig. 2). In case of post larvae the whole larvae was pooled and DNA was extracted using a commercial DNA extraction kit (Qiagen, 
Germany). The extracted DNA was then suspended in $50 \mu \mathrm{l}$ of nuclease free water.

PCR diagnosis of WSSV and EHP were carried out using the published protocols of Van Hulten et al., (2001) and Jaroenlak et al., (2016) respectively. The PCR amplification was carried out in a thermal cycler ((BIORAD T100 Thermal cycler, USA) in a total volume of $25 \mu \mathrm{L}$ reaction mixture containing 2X mastermix RED (Ampliqon Taq DNA polymerase, Denmark) $1.0 \mu \mathrm{L}(10 \mathrm{pmol})$ of forward and reverse primer each and $1.0 \mu \mathrm{L}$ $(50 \mathrm{ng})$ of DNA extracted from sample.

PCR products were separated on $1.5 \%$ agarose gel containing $0.2 \mu \mathrm{g} / \mathrm{mL}$ ethidium bromide alongside $3 \mu \mathrm{l} 100 \mathrm{bp}$ DNA ladder (GeneDirex) and the amplified DNA was visualized under UV illumination using a gel documentation system (BIO-RAD, USA).

\section{Results and Discussion}

Among the total number of 171 samples screened for WSSV and EHP by PCR, 84 samples $(49.12 \%)$ were positive for WSSV samples of $P$. vanammei screened by PCR (Figure 3), 54 samples (hepatopancreas) were found to be positive for EHP in the first step, resulting in the amplification of $514 \mathrm{bp}$ product which reveals that the sample is heavily infected (Figure 4).

However in the nested PCR $60 P$. vanammei samples $(66.66 \%)$ were positive, showing specific amplification at the $148 \mathrm{bp}$ fragment of EHP (Figure 5). The overall prevalence's of diseases caused by WSSV and EHP in the $P$. vanammei farms located at Nagapattinam district were $49.12 \%$ and $66.66 \%$ respectively (Table 2).

Table.1 Location coordinates of sampling areas

\begin{tabular}{|c|c|c|}
\hline Location & Latitude & Longitude \\
\hline Nagoore & $10^{\circ} 49^{\prime} 14.5^{\prime \prime} \mathrm{N}$ & $79^{\circ} 49^{\prime} 59.8^{\prime \prime} \mathrm{E}$ \\
\hline Kallimedu & $10^{\circ} 29^{\prime} 36.8^{\prime \prime} \mathrm{N}$ & $79^{\circ} 49^{\prime} 23.3^{\prime \prime} \mathrm{E}$ \\
\hline Vettaikaran iruppu & $10^{\circ} 33^{\prime} 20.0^{\prime \prime} \mathrm{N}$ & $79^{\circ} 49^{\prime} 48.7^{\prime} \mathrm{E}$ \\
\hline Velanganni & $10^{\circ} 40^{\prime} 35.4^{\prime \prime} \mathrm{N}$ & $79^{\circ} 50^{\prime} 04.9^{\prime \prime} \mathrm{E}$ \\
\hline Karuvelankadai & $10^{\circ} 44^{\prime} 29.6^{\prime \prime} \mathrm{N}$ & $79^{\circ} 50^{\prime} 08.8^{\prime \prime} \mathrm{E}$ \\
\hline Periyathambur & $10^{\circ} 66^{\prime} 83.6^{\prime \prime} \mathrm{N}$ & $79^{\circ} 81^{\prime} 14.6^{\prime} \mathrm{E}$ \\
\hline Chinathambur & $10^{\circ} 67^{\prime} 76^{\prime \prime} \mathrm{N}$ & $79^{\circ} 81^{\prime} 64^{\prime \prime} \mathrm{E}$ \\
\hline Sembodai & $10^{\circ} 46^{\prime} 19^{\circ} \mathrm{N}$, & $79^{\circ} 82^{\prime} 41^{\circ} \mathrm{E}$ \\
\hline Thopputhurai & $10^{\circ} 24^{\prime} 13.5^{\prime} \mathrm{N}$ & $79^{\circ} 51^{\prime} 37.6^{\prime} \mathrm{E}$ \\
\hline Vellapallam & $10^{\circ} 32^{\prime} 54.4^{\prime \prime} \mathrm{N}$ & $79^{\circ} 49^{\prime} 26.3^{\prime \prime} \mathrm{E}$ \\
\hline
\end{tabular}

Table.2 Prevalence of diseases caused by WSSV and EHP in P. vanammei farms at Nagapattinam district, Tamil Nadu

\begin{tabular}{|c|c|c|c|c|c|c|c|c|}
\hline \multirow[t]{3}{*}{ Sl.no } & \multirow[t]{3}{*}{ Sample } & \multirow{3}{*}{$\begin{array}{l}\text { No. of samples } \\
\text { screened }\end{array}$} & \multicolumn{5}{|c|}{ PCR results } & \multirow{2}{*}{$\begin{array}{l}\text { Prevalence } \\
(\%)\end{array}$} \\
\hline & & & \multicolumn{3}{|c|}{ Positive } & & Negative & \\
\hline & & & Disease & I step & Nested Step & Total & & \\
\hline 1 & Gill of P.vanammei & 171 & WSSV & -------- & -------- & 84 & 87 & $49.12 \%$ \\
\hline 2 & HP of $P$. vanammei & 171 & EHP & 54 & 60 & 114 & 57 & $66.66 \%$ \\
\hline
\end{tabular}


Figure.1 and 2 DNA was extracted from the gills and hepatopancreas of $P$. vanammei
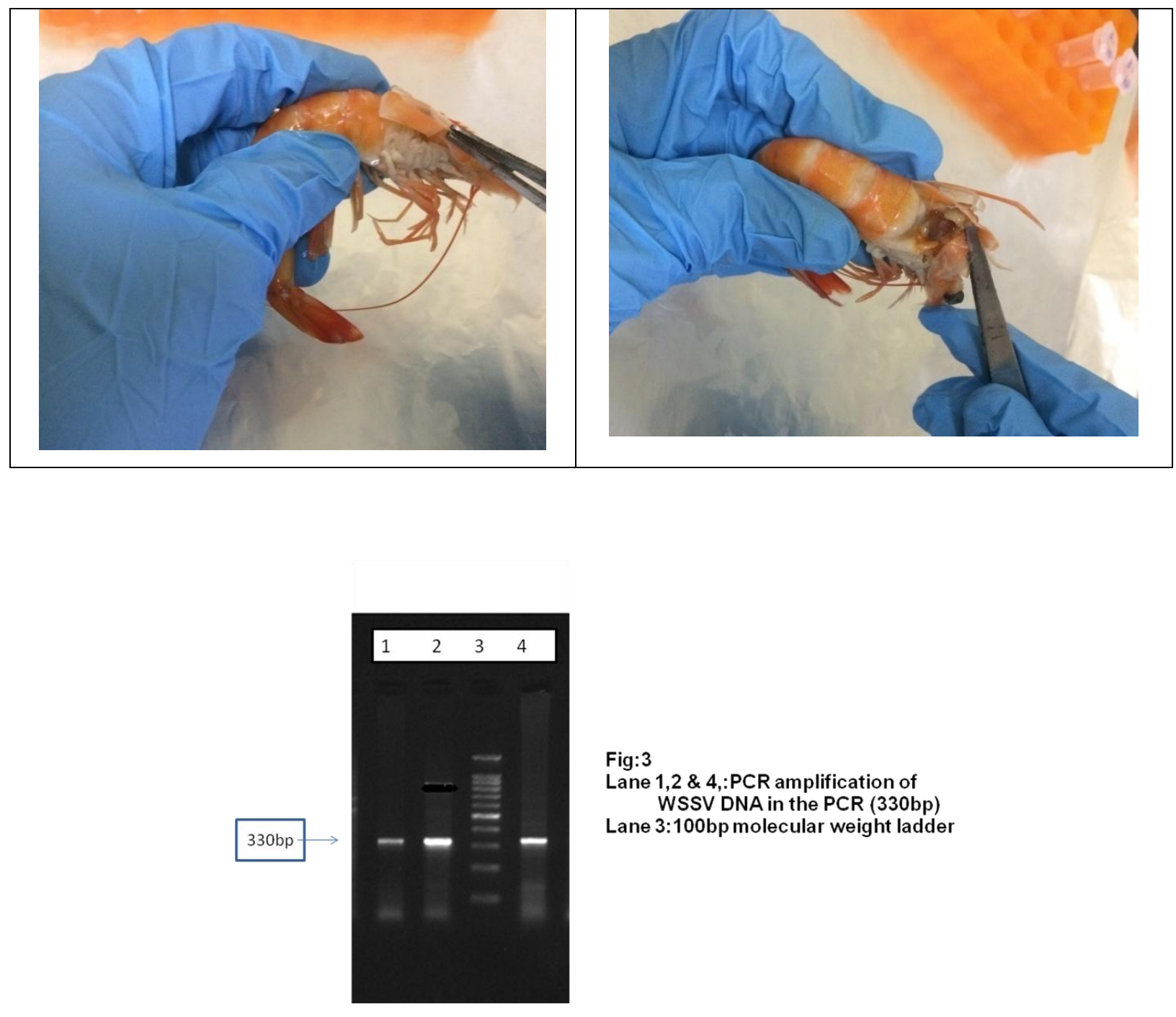

Fig:3

Lane 1,2 \& 4,:PCR amplification of WSSV DNA in the PCR (330bp)

Lane 3:100bp molecular weight ladder

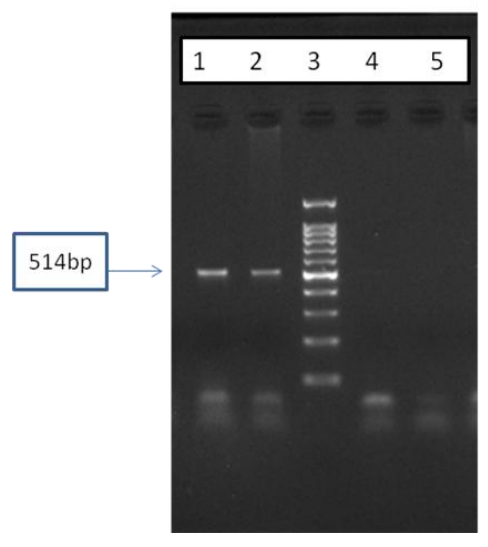

Fig: 4

Lane 1 \& 2:PCR amplification of EHP DNA in the $1^{\text {st }}$ step PCR (514bp) Lane 3:100bp molecular weight ladder 


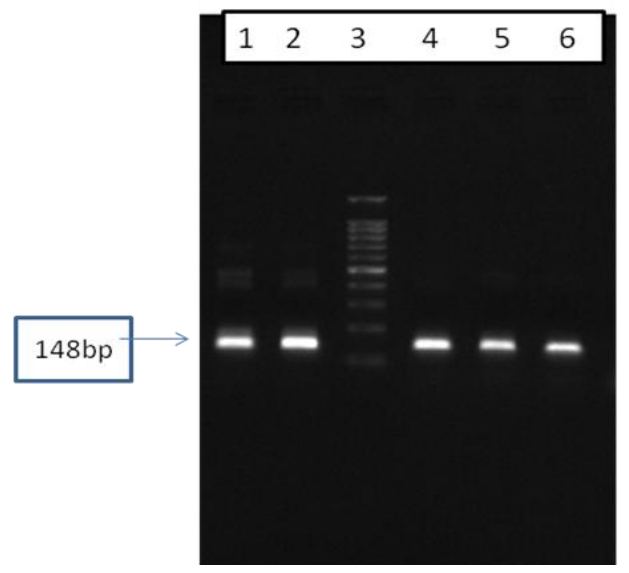

High prevalence of WSSV has been reported in samples collected from $P$. vannamei farms in Nagapattinam district. The About $49.12 \%$ prevalence recorded for WSSV pathogens was comparatively lower than the $80 \%$ and 75\% occurrence reported (Otta et al., 1999 and Otta et al., 2014) from the west coast of India and higher compared to the $39.4 \%$ prevalence reported by Uma et al., 2005 from south coast of India.

Tourtip et al., 2009 reported a new microsporidian parasite in $P$. monodon. E. hepatopenaei which was reported in pond reared $P$. vannamei in Vietnam, china Indonesia and Malaysia (Ha et al., 2010 and Tang et al., 2015). In India white feaces and reduced growth associated with EHP infestation has caused severe production losses to the shrimp farmers and the first report on prevalence of EHP causing hepatopancreatic microsporidiosis was reported in 2016 (Rajendran et al., 2016). In the present study, the PCR protocol reported by Jaroenlak et al., (2016) was followed to screen the collected shrimp samples. The prevalence of hepatopancreatic microsporidiosis recorded in the present study was $66.66 \%$ (114/171). An earlier study by Rajendran et al., (2016) has documented a lower prevalence a rate of $63.5 \%$ by the nested PCR. However, higher prevalence was documented by Biju et al., (2016) at a rate of
Fig: 5

Lane 1,2,4,5 \&6:PCR amplification of EHP DNA in the $2^{\text {nd }}$ step (nested) PCR (148bp)

Lane 3:100bp molecular weight ladder
69\%. The prevalence of EHP in the hepatopancreatic tissue of $P$. vanammei was recorded around $66.66 \%$ which is comparatively higher that the earlier report (Giridharan and Uma., 2017). EHP spreads through spores which can remain viable up to six months to one year in the aqueous condition like pond water or soil. Higher prevalence rate of EHP (66.66\%) compared to WSSV shows the need for the adoption of better management practices for the prevention and control of disease caused by EHP. There is no drug for the control of EHP infection in shrimp. Hepatopancreatic microsporidiosis does not cause any mortality but it is seriously associated with growth retardation in $P$. vannamei (Thitamadee et al., 2016) there by affecting the production and profits in commercial shrimp farming. Application of lime and maintaining soil $\mathrm{pH}$ to 12 has been suggested for the disinfection of ponds (CIBA, 2016). The recommended management measure for E. hepatopenai is to treat the water with calcium hypochloride at a rate of $18 \mathrm{mg} / \mathrm{l}$, treating the hatchery facilities using $2.5 \%$ sodium hydroxide solution with a contact time of three hours and rinsing using acidified chlorine and inactivation of EHP spores in shrimp ponds can be done by using quick lime at a rate of 6 tons/hectare and maintain the moist soil at a $\mathrm{pH}$ level of 12 for few days Sritunyalucksana et al., (2014). The usage of negative EHP post larvae in farms 
and burnt lime application during pre stocking period reduces the incidence of EHP in $P$. vanammei ponds (Sritunyalucksana et al., 2014).

\section{References}

Biju, N., Sathiyaraj, G., Raj, M., Shanmugam, V., Baskaran, B., Govindan, U., and Yohannan, R, 2016. High prevalence of Enterocytozoon hepatopenaei in shrimps Penaeus monodon and LitoPenaeus vannamei sampled from slow growth ponds in India. Diseases of Aquatic Organisms, 120, 225-230.

Cai, S., Huang, T., Wang, C., Song, X., Sun, X., Yu, J., Zhang Y., and Yang C, 1995. Epidemiological studies on the explosive epidemic disease of prawn in $1993-94$. J. Fish China, 19, 112-117.

Chang, P. S., Lo, C. F., Wang, Y. C., and Kou, G. $\mathrm{H}$, 1996. Identification of white spot syndrome associated baculovirus (WSBV) target organs in the shrimp Penaeus monodon by in situ hybridization. Dis. Aquat. Org, 27, 131139.

Chavadej, J., and Withyachumnarnkul, B, 2009. Enterocytozoon hepatopenaei sp. nov. (Microsporida: Enterocytozoonidae), a parasite of the black tiger shrimp Penaeus monodon (Decapoda: Penaeidae): Fine structure and phylogenetic relationships. J. Inv. Pathol. 102(1), 21-29.

Chou, H.Y., Huang, C.Y., Wang, C.H., Chiang H.C., and Lo, C.F, 1995. Pathogenicity of a baculovirus infection causing white spot syndrome in cultured penaeid shrimp in Taiwan. Dis Aquat Org, 23,165-173

Ha, N.T., Ha, D.T., Thuy N.T., and Lien, V.T.K, 2010. Enterocytozoon hepatopenaei parasitizing on tiger shrimp (Penaeus monodon) infected by white feces culture in Vietnam has been detected (In Vietnamese with English abstract). Agriculture and rural development: science and technology (translation from Vietnamese), 12, 45-50.

Inouye, K. S., Miwa, N., oseka, H., Nakano, T., Kimura, K., Momoyama and Hiroka M,
1994. Mass mortality of cultured kuruma shrimp $P$. japonicus in japan in 1993: electron microscopic evidence of the causative virus. Fish Pathol, 29, 149-158.

Jaroenlak, P., Sanguanrut, P., Williams, B. A. P., Stentiford, G. D., Flegel, T. W., Sritunyalucksana K., and Itsathitphaisarn, O, 2016. A Nested PCR Assay to Avoid False Positive Detection of the Microsporidian Enterocytozoon hepatopenaei (EHP) in Environmental Samples in Shrimp Farms. PLOSONE| DOI:10.1371/journal.pone.0166320.

Karunasagar, I., Otta, S. K., and Karunasagar, I, 1997. Histopathological and bacteriological study of white spot syndrome of Penaeus monodon along west coast of India. Aquaculture, 153, 913.

Lightner, D. V., 1996. In A Handbook of Shrimp Pathology and Diagnostic Procedures for Disease of Cultured Penaeid Shrimp, The World Aquaculture Society, Baton Rouge Lousiana, USA, 305p.

Lo, C.F., Ho, C.H., Peng, S.E., Chen, C.H., Hsu, H.C., Chiu, Y.L., Chang, C.F., Liu, K.F., Su, M.S., Wang, C.H., and Kou, G.H, 1996. White spot syndrome baculovirus (WSBV) detected in cultured and captured shrimps, crabs and other arthropods. Dis. Aquat. Org, 27, 215 225.

Nakano, H., Koube, H., Umezawa, S., Momoyama, K., Hiraoka, M., Inouye, K., and Oseko, N, 1994. Mass mortalities of cultured kuruma shrimp, Penaeus japonicus, in Japan in 1993: epizootiological survey and infection trials. Fish Pathol, 29:135-139 (in Japanese).

Otta, S. K., Shuba, G., Joseph, B., Chakraborthy, A., Karunasagar, I., and Karunasagar, I, 1999. Polymerase chain reaction (PCR) detection of white spot syndrome virus (WSSV) in cultured and wild crustaceans in India. Dis. Aquat. Org, 38, 67-70.

Otta, S.K., Arulraj, R., Praveena, P.E., Manivel, R., Panigrahi, A., Bhuvaneswari, T., Ravichandran, P., Jithendran, P.K., and Ponniah, A.G, 2014. Association of dual viral infection with mortality of Pacific 
white shrimp (Litopenaeus vannamei) in culture ponds in India. Virus Dis. 25(1), 63-68.

Rajendran, K. V., Shivam, S., Ezhil Praveena, P., Joseph Sahaya Rajan, J., Sathish Kumar, T. Avunje, S., and Vijayan, K. K, 2016. Emergence of Enterocytozoon hepatopenaei (EHP) in farmed Penaeus (Litopenaeus) vannamei in India. Aquaculture. 454, 272-280.

Sriurairatana, S., Boonyawiwat, V., Gangnonngiw W., and Laosutthipong, C, 2014. White feces syndrome of shrimp arises from transformation, sloughing and aggregation of hepatopancreatic microvilli into vermiform bodies superficially resembling gregarines. PLoS ONE 9(6): e99170

Tang, K. F. J., Pantoja, C. R., Redman, R. M., Han, J. E., Tran, L. H., and Lightner, D. V,2015. Development of in situ hybridization and PCR assays for the detection of Enterocytozoon hepatopenaei (EHP), a microsporidian parasite infecting penaeid shrimp. J. Inv. Pathol, 130, 3741.

Tangprasittipap, A., Srisala, J., Chouwdee, S., Somboon, M.; Chuchird, N.; Limsuwan, C., and Sritunyalucksana, K, 2013. The microsporidian Enterocytozoon hepatopenaei is not the cause of white feces syndrome in white leg shrimp Penaeus (Litopenaeus) vannamei. BMC. Vet. Res, 9(1), 139.

Thitamadee, S., Prachumwat, A., Srisala, J.,
Jaroenlak, P., Salachan, P. V.; Sritunyalucksana, K., and Itsathitphaisarn, O, 2016. Review of current disease threats for cultivated penaeid shrimp in Asia. Aquaculture, 452, 69-87.

Tourtip, S., Wongtripop, S., Stentiford, G. D., Bateman, K. S., Sriurairatana, S., Uma, A.,Koteeswaran, A., and Indrani Iddya, K, 2005. Prevalence of white spot syndrome virus and monodon baculovirus in Penaeus monodon broodstock and postlarvae from hatcheries in southeast coast of India. Curr sci, 89, 1619-1622.

Van Hulten, M.C., Witteveldt, J., Snippe, M., and Vlak, J.M, 2001. White spot syndrome virus envelope protein VP28 is involved in the systemic infection of shrimp. Virology 285, 228-233.

Wang, C.H., Lo, C.F., Leu, J.H., Chou, C.M., Yeh, P.Y., Chou, H.Y., Tung, M.C., Chang, C.F., Su, M.S., and Kou, G.H, 1995. Purification and genomic analysis of baculovirus associated with white spot syndrome (WSBV) of Penaeus monodon. Dis Aquat Org, 23,239-242.

Wongteerasupaya, C., Vickers, J.E., Sriurairatana, S., Nash, G.L., Akarajamorn, A., Boonsaeng, V., Panyim, S., Tassanakajon, A., Withyachumnarnkul, B., and Flegel, T.W, 1995. A non-occluded, systemic baculovirus that occurs in cells of ectodermal and mesodermal origin and causes high mortality in the black tiger prawn Penaeus mondon. Dis. Aquat. Org, $21,69-77$.

\section{How to cite this article:}

Rathipriya, A., T. Anand, A. Uma and Karal Marx, K. 2019. Prevalence of Diseases caused by White Spot Virus and Enterocytozoon hepatopenaei in Penaeus Vannamei Shrimp Farms in Nagapattinam District, Tamil Nadu, India. Int.J.Curr.Microbiol.App.Sci. 8(06): 2616-2622. doi: https://doi.org/10.20546/ijcmas.2019.806.314 